\title{
Effect of chicken genotype on growth performance and feed consumption in the development of broiler lines
}

Amusan, S.A., ${ }^{1}$ Ikeobi, C.O.N., ${ }^{1}$ Adebambo, A.O., ${ }^{1}$ Agaviezor, B.O., ${ }^{3}$ Wheto Mathew., ${ }^{1}$ Durosaro. S.O,. ${ }^{1}$ Adenaike, A.S., ${ }^{1}$ Ilori , B.M,. ${ }^{1}$ Adedeji, T.A., ${ }^{* *}$ and Adebambo, Olufunmilayo. ${ }^{1}$

${ }^{1}$ Department of Animal Breeding and Genetics, University of Agriculture, Abeokuta, Nigeria.

${ }^{2}$ Department of Animal Production and Health, Ladoke Akintola University of Technology, Ogbomoso, Nigeria. ${ }^{3}$ Department of Animal Science and Fisheries, University of Port Harcourt,

Port Harcourt, Nigeria

Corresponding author: amusansamuel@gmail.com

\section{Abstract}

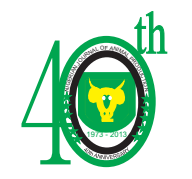

This experiment was conducted to assess the effect of chicken genotype on the growth performance, feed intake and feed efficiency of the progenies resulting from pure, straight and reciprocal cross of Giriraja (Gr) and Alpha chickens. Data obtained on body weight, body length, breast girth, keel length, feed intake and feed efficiency were analyzed using general linear models analysis of variance. Generally, all growth traits and feed consumption characteristics were significantly affected $(P<0.05)$ by chicken genotype. Growth traits and feed intake increased as birds advanced in age. Giriraja X Giriraja purebred chickens had the highest body weight, breast girth, feed intake and feed conversion efficiency through out the experimental period. However, the progenies resulting from the reciprocal crosses of Alpha X Gr had significant higher body weight and keel. Also, the feed conversion efficiency of the reciprocal crosses were better than the dihybrid cross progenies. The results therefore suggest that the superiority exhibited by the Giriraja could be utilized to improve the growth performance of the indigenous chicken thereby speed up desirable progress in the improvement of the indigenous broiler line.

Key words: Chicken, Crossbred, Feed consumption, Genotype, Growth trait, Purebred

\section{Introduction}

The total poultry population in Nigeria is estimated at 104,257,960 (RIMS, 1992), out of which the indigenous chicken constitute 75 to $80 \%$ of the total population (Trait, 1980). They are generally characterized by poor growth, small body size, small egg size as well as slow growth rate. These qualities are however not desirable in an economic situation. Moreover, these indigenous breeds have not been thoroughly worked upon in order to explore their adaptive genetic potentials. National or regional breeding programme based on gene pools of indigenous strains is also lacking. However, with the preponderance of indigenous chicken population in Nigeria, adequate developmental breeding plans will no doubt improve indigenous poultry production, enhance foreign exchange earnings (Ibe, 1990) and limits genotype-environment interaction (Akinokun, 1990) affecting exotic chicken in Nigeria. One of the major problems of the poultry industry in Nigeria is the lack of breeds of chicken that are adapted to the traditional small-scale production system prevalent in the area. There is the need to expand the narrow genetic base of the poultry industry in 
Nigeria to include the indigenous species as contributors of rare genes. Interestingly, introduction of a new genetic potential from the exotic breeds will speed up the process of genetic progress by the creation of hybrid vigour. There is therefore the need for breeding policies that will involve the production of improved local chicken through cross-breeding with the exotic breed. This research therefore seeks to study the growth performance of purebred and crossbred involving straight and reciprocal crossing of both improved indigenous and exotics with a view to develop a broiler line that will be able to cope with available local feed resources in Nigeria environment.

\section{Materials and Methods Description of study area}

The research was carried out at the Poultry Breeding Unit of the Teaching and Research Farm of the Federal University of Agriculture, Abeokuta, Nigeria. The area is located on $7^{\circ} 10^{\prime} \mathrm{N}$ and $3^{\circ} 2^{\prime} \mathrm{E}$ in Odeda Local Government Area of Ogun State, Nigeria. This area lies in the SouthWestern part of Nigeria and has a prevailing tropical climate with a mean annual rainfall of about $1037 \mathrm{~mm}$. The study lasted for 12 weeks.

\section{Experimental birds}

The experimental birds comprised of the exotic Giriraja (Gr) and Improved Indigenous (Alpha) chickens which were maintained at the Poultry Breeding Unit of the University of Agriculture, Abeokuta, Nigeria. The breeding cocks and hens were housed separately in two-tier battery cages. The birds were individually wing.-tagged along sire and dam lines for identification purposes. The breeders were fed ad libitum on compounded diet supplying $16 \%$ crude protein, $10.9 \mathrm{KJ} / \mathrm{g}$ metabolizable energy, $3.2 \%$ calcium and $0.45 \%$ (available) phosphorus.

The description of the experimenter birds is as shown below:

Giriraja 100\% dual-purpose exotic Alpha ()-breed $\quad 38$ to $50 \%$ local, 50 to $62 \%$ exotic bred for higher reproductive efficiency. (Adebambo et al., 2000)

\section{Semen Collection}

Semen was collected from each sire by the massage technique described by Lake (1962) and subsequently, each dam was artificially inseminated. The mating procedure involved includes, the straight, reciprocal and dihybrid crosses.

The mating procedure is as follows:

Giriraja (Gr) male x Giriraja (Gr) female straight crossing

Giriraja (Gr) male x Alpha female -

-- Reciprocal crossing

Alpha male x Giriraja(Gr) female-\}

\section{Egg collection and incubation}

Eggs were collected twice from the inseminated females and pedigreed along sire and dam lines and stored over a period of one week in a cool room having 50\% relative humidity. Proper cleaning, disinfection and fumigation of the incubator were done before setting of eggs along the genotype lines. The eggs were subsequently turned automatically through $90^{\circ}$ in the incubator. All chicks that resulted from each mating were properly identified, wing tagged and vaccinated against Marek's disease before been transferred to previously disinfected pen in the brooding unit. The chicks were fed ad libitum on a broiler starter that supplied $20-23 \%$ crude protein for a period of 4 weeks and finisher diet that contains $17-20 \%$ crude protein for the remaining eight weeks. Clean water was supplied ad libitum throughout the experimental period. 
Amusan, Ikeobi, Adebambo, Agaviezor, Wheto Mathew., Durosaro. Adenaike, Ilori, Adedeji, and Adebambo, Olufunmilayo

\section{Data collection}

The chicks were wing-tagged along sire lines and weighed with an Acculab electronic sensitive scale. Growth traits and feed intake of each bird were obtained on the first week and subsequently at four week interval till 12 weeks $(1,4,8$, and 12$)$. The growth traits measured were the body weight, breast girth, keel length and body length. The feed intake was measured by the subtraction of daily feed left over from feed initially supplied (gramme) and this was later used to calculate the feed efficiency for each cross.

Body weight $(B W)$ :- This was measured with the use of a sensitive balance with a maximum capacity of $2000 \mathrm{~g}$.

Breast girth $(B G)$ :- This was taken as the circumference of the breast around the deepest region of the breast. A tape rule calibrated in centimeters was used to take the measurement in centimetre

Keel length $(K L)$ :- This was taken as the length of the sternum. A tape rule was used to take the measurement in centimetre

Body length (BDL):- It was measured as the distance between the base of the neck and the cloaca. A tape rule was used to take the measurement in centimeter

\section{Data analysis}

The preliminary analyses reveal that sex of the progenies had significant effects $(\mathrm{P}<$ 0.05 ) on all the growth traits, feed intake and feed efficiency; therefore, the raw data was subsequently adjusted for sex effect. Adjusted data was then analysed using a one-way analysis of variance for the fixed effect of genotype using the general linear models (GLM) procedure of Statistical Analysis System (2003). The model is as shown below:

$\mathrm{Y}_{\mathrm{ij}}=\mu+\mathrm{G}_{\mathrm{i}}+\varepsilon_{\mathrm{ij}}$

Where:

$\mathrm{Y}_{\mathrm{ij}}=$ dependent variable $\mu=$ overall mean when equal sub-class frequencies exist

$\mathrm{G}_{\mathrm{i}}=$ Effect of the ith genotype $(\mathrm{i}=1,2,3,4)$

$\varepsilon_{\mathrm{ij}}=$ Random residual error normally distributed with zero mean and variance, $\mathrm{e}^{2}$

\section{Results and Discussion}

Tables 1,2, 3 and 4 showed the least square means of body weight, body length, breast girth and keel length as affected by chicken. Generally, there were significant genotype differences $(\mathrm{P}<0.05)$ in body weight, body length, breast girth and keel length of straight, reciprocal and di-hybrid progenies. All the growth traits increased as birds advanced in age. The least square means of body weight generally revealed that the progenies of the straight cross ( $\mathrm{Gr} \mathrm{X}$ Gr) had more body weight followed by the progenies of reciprocal crosses. Similarly, the highest breast girth were obtained in the progenies of the straight cross but not significantly $(\mathrm{P}<0.05)$ different from those of the reciprocal crosses. The highest body length and keel length were obtained in the progenies of reciprocal crosses. That is, the use of Giriraja to mate the Alpha chickens greatly improved the body length and keel length of their progenies.

Chicken's genotype significantly affected $(\mathrm{P}<0.05)$ feed intake and feed efficiency. Feed intake and feed efficiency increased consistently with the age of the birds (Tables 5 and 6). The least square means revealed that the progenies of the straight cross (Gr X Gr) generally consumed more feed than other genotypes. However, Alpha (Male) X Gr (Female) consistently consumed less feed (Table 5). Interestingly, the highest feed efficiency was obtained in the straight cross progenies followed by the reciprocal crosses while and dihybrid cross progenies were the least efficient (Table 6). 
Effect of chicken genotype on growth performance of broiler lines

Table 1: Least square means of genotype effect on body weight (g)

\begin{tabular}{lccccc}
\hline \multicolumn{7}{c}{ Weeks } \\
GENOTYPE & $\mathrm{N}$ & $\mathrm{1}$ & 4 & 8 & 12 \\
\hline GR(M) X GR(F) & 32 & $51 \pm 2.64^{\mathrm{a}}$ & $245 \pm 17.39^{\mathrm{a}}$ & $784 \pm 31.31^{\mathrm{a}}$ & $1273 \pm 51.50^{\mathrm{a}}$ \\
GR(M) X ALPHA(F) & 13 & $51 \pm 3.55^{\mathrm{a}}$ & $162 \pm 11.86^{\mathrm{b}}$ & $617 \pm 11.15^{\mathrm{b}}$ & $1008 \pm 32.60^{\mathrm{b}}$ \\
ALPHA(M) X GR(F) & 10 & $45 \pm 1.99^{\mathrm{b}}$ & $256 \pm 26.87^{\mathrm{a}}$ & $609 \pm 44.62^{\mathrm{b}}$ & $1017 \pm 40.87^{\mathrm{b}}$ \\
\hline
\end{tabular}

Table 2: Least square means of genotype effect on body length $(\mathrm{cm})$

\begin{tabular}{llcccc}
\hline \multicolumn{5}{c}{ Weeks } \\
\hline GENOTYPE & $\mathrm{N}$ & 1 & 4 & 8 & 12 \\
\hline GR(M) X GR(F) & 32 & $5.05 \pm 0.22^{\mathrm{b}}$ & $11.39 \pm 0.47^{\mathrm{b}}$ & $19.48 \pm 0.37^{\mathrm{a}}$ & $25.87 \pm 0.65^{\mathrm{b}}$ \\
GR(M) X ALPHA(F) & 13 & $5.89 \pm 0.16^{\mathrm{a}}$ & $11.00 \pm 0.26^{\mathrm{a}}$ & $17.54 \pm 0.35^{\mathrm{b}}$ & $23.69 \pm 0.28^{\mathrm{c}}$ \\
ALPHA(M) X GR(F) & 10 & $3.06 \pm 0.35^{\mathrm{c}}$ & $11.78 \pm 0.46^{\mathrm{b}}$ & $19.40 \pm 0.83^{\mathrm{a}}$ & $29.87 \pm 0.64^{\mathrm{a}}$ \\
\hline
\end{tabular}

\section{Discussion}

Increase in all body measurements of individuals in each genotype as growth advanced is expected and also agrees with the reports of Pingel et al. (1990) that age is a major determinant of growth and physiological development. The results of this investigation showed that genotype significantly affected body weight and linear body measurements of all the chickens used for this study. The significant genotype differences in body weights and linear body measurements among the chickens showed that they were highly influenced by genetic factors and this agrees with the reports of Ikeobi and Peters (1996), and Ibe and Nwosu (1999). The superiority in body weight exhibited by the crosses from the exotic birds (Giriraja) suggests that they have a better growth potential than the others. This may be due to the fact that this breed (Giriraja) had undergone series of improvement and selection for higher body weight and growth rate. The lower values recorded by the crosses that involved the White Leghorn and Alpha crosses can be attributed to the fact that they are classified as light breeds.

Table 3: Least square means of genotype effect on breast girth $(\mathrm{cm})$

\begin{tabular}{lccccc}
\hline & \multicolumn{5}{c}{ Weeks } \\
\hline GENOTYPE & $\mathrm{N}$ & 1 & 4 & 8 & 12 \\
\hline Gr (M) X Gr (F) & & & & & \\
Gr (M) X ALPHA (F) & 13 & $7.76 \pm 0.16^{\mathrm{a}}$ & $9.91 \pm 0.23^{\mathrm{a}}$ & $16.17 \pm 0.37^{\mathrm{ab}}$ & $22.72 \pm 0.78^{\mathrm{a}}$ \\
ALPHA (M) X Gr (F) & 10 & $6.17 \pm 0.17^{\mathrm{c}}$ & $9.62 \pm 0.23^{\mathrm{a}}$ & $17.15 \pm 0.41^{\mathrm{a}}$ & $21.62 \pm 0.33^{\mathrm{ab}}$ \\
\hline
\end{tabular}

Table 4: Least square means genotype effect on keel length $(\mathrm{cm})$

\begin{tabular}{lccccc}
\hline \multicolumn{5}{c}{ Weeks } \\
\hline GENOTYPE & $\mathrm{N}$ & 1 & 4 & 8 & 12 \\
\hline Gr (M) X Gr (F) & 32 & $3.13 \pm 0.18^{\mathrm{b}}$ & $6.59 \pm 0.21^{\mathrm{c}}$ & $13.44 \pm 0.54^{\mathrm{ab}}$ & $19.18 \pm 0.89^{\mathrm{b}}$ \\
Gr (M) X ALPHA (F) & 13 & $3.68 \pm 0.15^{\mathrm{a}}$ & $7.70 \pm 0.36^{\mathrm{ab}}$ & $14.77 \pm 0.26^{\mathrm{a}}$ & $21.62 \pm 0.41^{\mathrm{a}}$ \\
ALPHA (M) X Gr (F) & 10 & $3.10 \pm 0.24^{\mathrm{b}}$ & $8.01 \pm 0.63^{\mathrm{a}}$ & $13.80 \pm 0.66^{\mathrm{a}}$ & $21.90 \pm 0.71^{\mathrm{a}}$ \\
\hline
\end{tabular}


Amusan, Ikeobi, Adebambo, Agaviezor, Wheto Mathew., Durosaro. Adenaike, Ilori, Adedeji, and Adebambo, Olufunmilayo

Table 5: Least square means genotype effect on feed intake (g)

\begin{tabular}{lccccc}
\hline \multicolumn{5}{c}{ Weeks } \\
\hline GENOTYPE & $\mathrm{N}$ & 1 & 4 & 8 & 12 \\
\hline Gr (M) X Gr (F) & 32 & $40 \pm 0.01^{\mathrm{a}}$ & $58 \pm 0.01^{\mathrm{a}}$ & $83 \pm 0.02 \mathrm{a}$ & $99 \pm 0.02^{\mathrm{a}}$ \\
Gr (M) X ALPHA (F) & 13 & $35 \pm 0.02^{\mathrm{b}}$ & $38 \pm 0.01^{\mathrm{b}}$ & $60 \pm 0.01^{\mathrm{bc}}$ & $96 \pm 0.00^{\mathrm{b}}$ \\
ALPHA (M) X Gr (F) & 10 & $30 \pm 0.01^{\mathrm{c}}$ & $35 \pm 0.01^{\mathrm{c}}$ & $59 \pm 0.01^{\mathrm{c}}$ & $90 \pm 0.00^{\mathrm{d}}$ \\
\hline
\end{tabular}

Table 6: Least square means genotype effect on feed efficiency

\begin{tabular}{lccccc}
\hline & \multicolumn{5}{c}{ Weeks } \\
\hline GENOTYPE & $\mathrm{N}$ & 1 & 4 & 8 & 12 \\
\hline Gr (M) X Gr (F) & 32 & $0.32 \pm 0.04^{\mathrm{c}}$ & $0.45 \pm 0.06^{\mathrm{b}}$ & $0.50 \pm 0.04^{\mathrm{b}}$ & $0.55 \pm-0.06^{\mathrm{c}}$ \\
Gr (M) X ALPHA (F) & 13 & $0.35 \pm 0.02^{\mathrm{a}}$ & $0.49 \pm 0.03^{\mathrm{a}}$ & $0.54 \pm 0.01^{\mathrm{a}}$ & $0.57 \pm 0.03^{\mathrm{b}}$ \\
ALPHA (M) X Gr (F) & 10 & $0.34 \pm 0.01^{\mathrm{b}}$ & $0.50 \pm 0.02^{\mathrm{a}}$ & $0.55 \pm 0.09^{\mathrm{a}}$ & $0.61 \pm 0.06^{\mathrm{a}}$ \\
\hline
\end{tabular}

Alpha or Improved Local is a cross of Nigerian local chicken which has been observed as a light breed. The better performance of the Giriraja crosses further proves that this strain is able to transmit the gene for faster growth into its progenies (Ibe 1993, Ebangi and Ibe 1994). This was clearly demonstrated with the better performance of the progeny for the period of study.

The variation in the values of linear body measurement (keel length, breast girth and body length) in all the crosses can be attributed to different genetic background (Peters, 2000). The superiority exhibited by F1 X GR over the other genotypes showed that the improved indigenous breed has a good combining effect with the Giriraja (exotic) when used as a male line rather than a female line. The result of this investigation is expected since the male line here is the improved indigenous cross which has $50 \%$ indigenous blood line which reduced the growth potential.

The fact that the performances of the crosses that involved the improved indigenous breed with the Giriraja were lower than that of the pure exotic breed
(Giriraja) was expected (Ibe, 1998). Ibe (1998) explained that the Nigerian indigenous chickens have gone through more of natural selection for survival in tropical climate rather than artificial selection for productivity. The results also indicated that the improved indigenous breed of chicken combined significantly well with the exotic strain to achieve an improved body weight as the paternal line rather than maternal line. More vigorous crossbreeding, selection and an improvement of the environment of the indigenous chicken would need to be pursued to improve on the growth potential in these strains.

The variation in the feed intake across the various genotypes used in this study was genetically influenced. The quantity of feed in grams eaten by different strains differed between strains (Adenowo et al. 1995). The results of the investigation agreed with observations of Agaviezor (2005) that genotype significantly affected feed efficiency and feed conversion ratio.

\section{Conclusion}

The greater effect of chicken genotype on 
body weight and linear body measurements coupled with better performances in the progenies of both straight and reciprocal crosses, introduction of exotic strains (Giriraja) into our indigenous chicken population will bring a desirable progress in the improvement of our indigenous species.

\section{References}

Agaviezor,. B. O. 2005. Genetic evaluation of laying performance of pure exotic and indigenous crossbred pullets. M. Agric. Dissertation. Dept. of Animal Breeding and Genetics. University of Agric. Abeokuta. Pp 76.

Akinokun, O. 1990. An evaluation of exotic and indigenous chicken as Genetic Materials for development of rural poultry in Africa. In: Proceedings of An International Workshop on Poultry Development In Africa held at the. Obafemi Awolowo University, Ile-ife, Nigeria 13-16 Nov. 1989 pp 3661.

Ebangi, A. C. and Ibe. S.N. 1994. Heritability and genetic correlations between some growth traits in. Nigeria's local chicken. Nig. J. Anim. Prod. 21: 19-24.

Ibe. S.N. 1990. Incorporating adaptability genes in poultry breeding Program in Nigeria. Proc. XIX. World's congress on genetic applied to livestock Production. Edinburgh, Scotland.

Ibe. S.M. 1993. Growth Performance of normal, frizzle and naked Chicken in a tropical Environment. Nig. J. Anim. Prod. 20:25-31.

Ibe. S.N. 1998. Improving productive adaptability of the Nigeria Local Chicken. In: Proceedings of the silver Anniversary conference of the
Nigerian Society for the Animal Production held at Gateway Hotel, Abeokuta, Nigeria 21-26 March, 1998. $46-465$.

Ibe. S. N., and Nwosu, U. F. 1999. Influence of naked neck and frizzle genes on early growth of chickens. Book of Proceedings. 26 ${ }^{\text {th }}$ Annual NSAP Conference $21-25$ March, Ilorin Nigeria. Pg 292295.

Ikeobi. C.O.N. and Peters, S.O. 1996. Strain differences in the genetic parameter estimates for growth trait in meat type chicken. Nigerian. Journal Animal Prod. 23:103-106.

Lake. P.E. 1962. Artificial insemination in poultry. In: Malie, J.P. (eds). The Semen of animals and Al Common Wealth Agric. Burean, Bucks, England, Pp 331-335.

Peters. S.O. 2000. Genetic variation in the reproductive performance of Indigenous chicken and the growth rates of its pure and half-bred progeny. M.Agric. Thesis. Dept. of Animal Breeding and Genetics. University of Agric. Abeokuta. Pp120.

Pingel. H. Schneider, K. H. and Birla, M. 1990. Factors affecting meat quality in broilers. Anim Breed. Abst. 59 (1). 1991.

RIMS. 1992. Nigerian Livestock Resources Vol. II National Synthesis and Resource Inventory Management Limited, Pp. 472.

Statistical Analysis System. 2003. Statistical Analysis System. SAS Stat. Version 9. SAS institute Inc. Gary NC 27513, U.S.A.

Trait. G.G.1980. Problems facing the Poultry Industry in Nigeria. Proc. $1^{\text {st }}$ continuing Education Seminal for veterinary officers, Ibadan, Nig. 285IP 